\title{
GARNISHIMENT OF INTANGIBLE DEBTS IN NEW YORK
}

\author{
WALTER B. KENNEDY
}

Conservatism is a deeply-imbedded characteristic of the law: Reforms come forth slowly and with expressions of regret for the passing of the old order. Even after they are accomplished there is a tendency to look back with longing glances and in sorne instances to revive the abandoned principles by artificial and forced construction of statutory changes. ${ }^{2}$ As Polloek figuratively phrases it:

"There are few departments of law where some stubborn bit of archaic form has not stood out, down to times within our own memory if not to this day, like a pile of ancient rock, weathered and denuded, but not yet worn down to the level of the plain where men dwell and work." 3

But withal, conservatism has its proper place in the development of the law; and even the sociological reformers and eritics of the legal order, sometimes provoked at the failure of the courts to translate their ambitious programs of uplift into the living law, may be confidently informed that progress and change are not synonymous terms in the legal lexicon.

These generalizations come to the surface in a review of the garnishment of intangible debts in the law of New York. In this state, as elsewhere, the formative stages of this form of attachment are clouded by fictions and formalism. Gradually but surely these fictions begin to disappear in the face of the realities of modern life and the emergencies of business. Yet we may still detect "some stubborn bit of archaic form" which persists even down to our own time, some frail form which has outlived its utility and is tenderly accepted at its face value despite the reversal of the foundations upon which it rests. Whether the

1 "We work over, adapt and modify, willingly, eagerly; but when it comes to casting out a whole policy and substituting a new one runnings contrary, we are against it, and because of our conservatism, our admiration for and confidence in what has been, we do not make much efrort to find out the merits of the new."-John G. Sargent, Attorney-General of the United States, address before the New York State Bar Associntion, N. Y. L. JouR, Jan. 23, 1926.

2 Twenty years elapsed after the passage of the Negotiable Instruments Law in New York (Laws, 1897, ch. 612) before its provision that "an antecedent debt constitutes value" (Laws, 1909, ch. 43, sec. 51) displaced the contrary common-law doctrine of Coddington v. Bay (1822, N. Y. Sup. Ct.) 20 Johns. 637; Kelso \& Co. v. Ellis (1918) 224 N. Y. 528, 121 N. E. 364.

3 Essays in the Law (1922) 199. 
necessary readjustments can be made by judicial action, or whether relief must be sought in legislation, may be debatable. But the importance of the garnishment process in the Empire State, with its magnitude of business based upon credits, renders it imperative to weigh carefully the validity and justice of these fragile fictions and forms to the end that they may be levelled to the plane "where men dwell and work".

When we attempt to fix the situs of a debt for purposes of jurisdiction or attachment, we leave the realms of reality and deal with fictions. A debt is a chose in action, not a chose in possession. Confining our analysis to an intangible debt, we do not search out its situs; we frankly confess that we are obliged to create one. 5 And this compulsory attempt to localize the debt is confused by its bisected form. It is divisible into two parts: the right of the creditor and the obligation of the debtor. If the creditor and the debtor reside in different states, the parts are no longer under the unified authority of one sovereign. Faced by these peculiar attributes of a debt, it was inevitable that the courts should endeavor to remove or lessen the resultant entanglements by resort to fictions. A favorite one in the past has been the fiction that the debt is located at the creditor's domicile, expressed in the maxim, mobilia sequuntur personam.

Whatever may be the merit or utility of this formula for the purposes of taxation or administration of debts, this legal assumption has suffered a rather complete eclipse in the rules of attachment and jurisdiction. In actions between the original creditor and debtor, the stated fixation of the debt at the creditor's domicile is not in itself sufficient to give jurisdiction over the debt; the debt is not a res which can be captured at this place

\footnotetext{
4 This paper and the resultant consideration of intangible debts excludes the discussion of debts which partake of the qualities of a specialtye.g. promissory notes, bonds, etc. The conclusion that the debt is intorwoven into the instrument itself frequently results in the establishment of a situs for these debts at the place where the instrument is found for the purposes of attachment and taxation. Beers $v$. Shannon (1878) 73 N. Y. 292; Matter of Whiting (1896) 150 N. Y. 27, 44 N. E. 715; Simpson v. The Jersey Contracting Co. (1900) 165 N. Y. 193, 58 N. E. 896; Lockwood v. United States Steel Corp. (1913) 209 N. Y. 375, 103 N. E. 697; Erslino v. Nemours Trad. Corp. (1924) 239 N. Y. 32, 145 N. E. 273; Matter of MoMullen (1922, 1st Dept.) 199 App. Div. 393, 192 N. Y. Supp. 49; Iratter of Lowell (1924, 1st Dept.) 208 App. Div. 201, 203 N. Y. Supp. 312; Blackstone v. Miller (1903) 188 U. S. 189, 23 Sup. Ct. 277; Buck v. Beach (1907) 206 U. S. 392, 27 Sup. Ct. 712; Wheeler v. Sohmer (1914) 233 U. S. 434, 34 Sup. Ct. 607 . See N. Y. C. P. A. 1921, sec. 916 ; N. Y. Surro. Ct. Act, sec. 47.

5 For the many divergent views regarding the situs of intangible debts, see Carpenter, Jurisdiction Over Debts (1918) 31 HARv. L. REv. 905; of. Beale, Jurisdiction in Rem to Compel Payment of a Debt (1913) 27 Harv. L. REv. 107.
} 
without reference to the debtor." Relief must be sought by pursuit of the debtor in a direct in personam action available at the latter's domicile ${ }^{\tau}$ or in a state where he has been personally served with process. ${ }^{8}$ To this extent the fiction that the debt is imbedded at the domicile of the creditor has been uprooted; and in its place has been implanted the cardinal principle which governs the seizure of tangibles, namely, that power to control is the jurisdictional requisite. And this power over debts-inter partes at least-involves the debtor as a necessary party, not because of any nimble fiction regarding the situs of the debt, but because of the palpable fact that the pocket-book of the debtor must give forth the satisfaction sought by his creditor. ${ }^{3}$

Turning to the garnishment of intangibles and seeking a situs wherein a debt may be reached, the same difficulties appear intensified by the tri-partite form of this process. Herein two rights or obligations are involved, the primary right between the plaintiff and the defendant, and the subsidiary obligation oving from the garnishee to the defendant, which is seized by the plaintiff and diverted to satisfy the plaintiff's claim. The confusion attending the exercise of garnishment centers about the nature and situs of the debt to be garnished. What are the steps to be taken by the plaintiff to reach this debt owing from the garnishee to the defendant? In what juxisdiction may the plaintiff institute garnishment proceedings with the assurance that he has satisfied the constitutional and common-law requirements of due process: at the domicile of the principal defendant; where the defendant is served with process; at the garnishee's domicile; or, where the garnishee is duly notified by the plaintiff? These elusive and overlapping questions are frequently arising in New York law and call for a careful and measured analysis of the nature and locale of debts for purposes of garnishment.

G McDonald v. ILabee (1917) 243 U. S. 90, 37 Sup. Ct. 343; Buchanaal $z$. Rucker (1808, K. B.) 9 East, 192; Schwinger v. Hickol (1873) 53 N. Y. 280 ; Durant v. Abendroth (1884) 97 N. Y. 132; Hantza i. Stedman (1921) 230 N. Y. 326, 130 N. E. 566; Korman v. Grand Lodge (190.t, Sup. Ct. T. T.) 44 Mise. 564, 90 N. Y. Supp. 120; De Veaux v. Paclinsliy (1918, Sup. Ct. App. T.) 169 N. Y. Supp. 1039; Szirtes v. Bly (1918, 1st Dept.) 185 App. Div. 274, 172 N. Y. Supp. 802.

T Schibsby v. Westenholz (1870) L. R. 6 Q. B. 155; Henderson v. Staniford (1870) 105 MIass. 504; Hunt v. Hunt (1878) 72 N. Y. 217; Contiocintal Bank v. Thurber (1893, N. Y. Sup. Ct.) 74 Hun, 632, aff'd (1804) 148 N. Y. 648,37 N. E. 828; cf. Grubcl v. Nassaucr (1913) 210 N. Y. 149, 103 N. E. 1113; Dicey, Conflict of Lav's (2d ed. 1908) 361; Carmody, N. I. Practice (1923) sec. 113.

${ }^{8}$ See cases in note 6 , supra. The writer, of course, is not considering the jurisdictional requirements of actions in rem or quasi-int-rcm.

${ }^{9}$ Blaclestone v. Miller, supra note 4; Fricle v. Pennsylanaia (1925) 265 U. S. 463, 45 Sup. Ct. 603; Seefurth, Recent Limitations on the Pouver to Impose Inheritance and Estate Tases (1925) 25 CoL. L. REv. 870. 
Assuming adequate jurisdiction over the defendant and the garnishee, the constitutionality and efficacy of the attachment of debts owing from the garnishee to the creditor-defendant is well established in the case of attachment prior to judgment ${ }^{10}$ and also in the case of levy upon execution. ${ }^{11}$ If the defendant in the main action and the garnishee are both domiciled in New York, the various theories regarding the situs of the debt to be trusteed become academic. Whether the debt is considered to be at the creditor's (defendant's) domicile or at the debtor's (garnishee's) domicile is immaterial in view of the assumption that both parties are domiciled in New York. The authorities bear out this initial conclusion. ${ }^{12}$

The more debatable and dubious parts of the garnishment process are reached when either the defendant or the garnishee, or both, are domiciled without New York. Three possible situations may arise to test the generality of this form of attachment when one of these elements is involved: (1) when the defendant is domiciled and the garnishee is not domiciled in New York; (2) when the garnishee is domiciled and the defendant is not domiciled in New York; and (3) when neither the defendant nor the garnishee is domiciled in New York.

\section{WHEN THE DEFENDANT IS DOMICILED AND THE GARNISHEE IS NOT DOMICILED IN NEW YORK}

If the defendant were suing the garnishee directly, the garnishee being a non-resident, ${ }^{13}$ the jurisdiction of New York would

${ }^{10}$ N. Y. C. P. A. $1921,916,917$; Russell v. Ruckman (1854, N. Y. C. P.) 3 E. D. Smith, 419; Wilson v. Duncan (1860, N. Y. Super. Ct.) 11 Abb. Pr. 3; O'Brien v. The Glenville Woolen Co. (1872) 50 N. Y. 128; O'Brion v. Mechanics \& T. Fire Ins. Co. (1874) 56 N. Y. 52; Greentrea v. Rosenstool (1875) 61 N. Y. 583; Hayden v. National Bl. (1891) 130 N. Y. 146, 29 N. E. 143; Courtney v. Eighth Ward Bank (1898) 154 N. Y. 688, 49 N. E. 54 ; Simpson v. Jersey Contracting Co., supra note 4; Amberg v. Manhattan Life Ins. Co. (1902) 171 N. Y. 314, 63 N. E. 1111; Rosenberg v. Occidental Trading Co. (1919) 185 App. Div. 330, 178 N. Y. Supp. 477; Erskine i. Nemours Trading Co., supra note 4.

11 N. Y. C. P. A. 1921, sec. 684; Laird v. Carton (1909) 196 N. Y. 169, 89 N. E. 822 ; Brearley School v. Ward (1911) 201 N. Y. 358, 94 N. E. 1001; Endicott Johnson Corp. v. Encyclopedia Press (1924) 266 U. S. 285, 45 Sup. Ct. 61.

12 See supra notes $10,11$.

13 The terms "residence" and "domicile" are used interchangeably in the text. This usage may not be technically accurate. Cf. Putnam v. Johnson (1813) 10 Mass. 488. But it is supported by the settled definitions of "resident" in the New York Constitution, statutes and decisions. N. Y. Const., Art. II, sec. 3; Tax Law, secs. 243, 350 (7) ; Matter of Barry (1900) 164 N. Y. 18, 58 N. E. 12; Matter of Barbour (1919, 1st Dept.) 185 App. Div. 445,173 N. Y. Supp. 276, aff'd 226 N. Y. 639, 123 N. E. 854; Matter of Blankford (1925) 241 N. Y. 180,149 N. E. 415 ; see editorial, N. Y. L. JouR., Dec. 2, 1925; (1926) 35 Yale Law Journat, 508, and 635. 
be dependent upon satisfactory service on the debtor in the state. ${ }^{\text {s }}$ If the garnishee were a foreign corporation, additional proof that the garnishee expressly ${ }^{15}$ or impliedly ${ }^{16}$ submitted to the laws of the place must be furnished before the creditor could validly subject the foreign corporation to the process of this state. These basic ingredients must be satisfied as preliminary conditions in order to reach this same debt by way of attachment; the right of the plaintiff to garnish is a derivative right which he must trace out through the defendant. The garnishee being a nonresident, orthodox principles of the common law'i and the constitutional mandate of due process ${ }^{18}$ will prevent the principal plaintiff from reaching over the head of the defendant and seizing the latter's credits in the hands of a non-resident garnishee. And the magic of the maxim, mobilia sequnnizu personam, which would fix the situs of the debt at the domicile of the defendantcreditor, fails to remove the stated requisite that calls for adequate notice to the garnishee within the forum. Reverting to the statutes, it appears that personal service within the state is a condition which must be complied with before the court can proceed against the non-resident garnishee, whether the garnishee is a foreign corporation or an individual. ${ }^{10}$

\section{WHEN THE GARNISHEE IS DOMICLED AND THE DEFENDANT IS NOT DOMICILED IN NEW YORI}

Dismissing the subsidiary remedy against the garnishee for the moment, it is to be noted that the plaintiff must first obtain jurisdiction over the defendant in the stated circumstances. Since the defendant is a non-resident, the plaintiff must serve upon the defendant personally in New York, or failing to efieet actual service, he must attach property of the defendant in the state. Lacking personal service or valid attachment, subsequent proceedings would be coram non judice, a mere judicial gesture

14 Supra note 6.

15 Stock Corp. Law, secs. 110-114; Smolile v. Pliladelplia \& Rcading C. \& I. Co. (1915, S. D. N. Y.) 222 Fed. 148; Bagdon v. Philadclphia \& Rcading C. \& I. Co. (1916) 217 N. Y. 432, 111 N. E. 1075; Pcnnoylerania Fire Ins. Co. v. Gold Issue Min. Co. (1917) 243 U. S. 93, 37 Sup. Ct. 211; cj. Mechanics \& MI. Nat. Bl. v. Banque Industricllc (1923, 1st Dept.) 205 App. Div. 543, 199 N. Y. Supp. 817; Comey v. Unitcd Surety Co. (1016) 217 N. Y. 268, 111 N. E. 832 .

16 Old Wayne MIutual Life Ass'n v. IIcDonough (1907) 204 U. S. 8, 27 Sup. Ct. 236; Simon v. Southem Rv. (1915) 236 U. S. 115, 35 Sup. Ct. 255; Tauza v. Susquehanna Co. (1917) 220 N. Y. 259, 115 N. E. 915; of. Bridges v. Wade (1906, 1st Dept.) 113 App. Div. 850, 99 N. Y. Supp. 120.

17 Buchanan v. Rucler, sipra note 6.

${ }^{18}$ Pennoyer v. Neff (1878) 95 U. S. 714; McDonald v. Mabcc, otupra note 6.

19 N. Y. C. P. A. 1921, secs. $684,917$. 
without legality, and offensive to the requirements of due process. ${ }^{20}$ Hence in cases where the defendant has not been served in New York, the valid exercise of the garnishment process not only subjects the garnishee to the jurisdiction of the court, but it also draws the defendant into the state to the extent of the debt attached. But is the debt in New York by virtue of the garnishee's domicile therein, so that it may be said that the plaintiff has seized property of the absent defendant? Not if the classic formula that the debt follows the creditor is applied to the present situation, for under this theory the elusive chose in action would be without the territory and beyond the reach of the local sovereign. Adhere to this fiction and the main action, as well as the provisional remedy of garnishment, must fall to the ground. But the convenient elasticity of fictions comes forth to prevent this inevitable result of fixing the debt at the domicile of the creditor. Formalism once more breaks down when the fiction fails to meet the exigencies of the situation; and we are told that the general rule that "the situs of debts and obligations is at the domicile of the creditor" is qualified by the exception that "the laws of a state, for the purposes of attachment proceedings, may fix the situs of a debt at the domicile of the debtor." ${ }^{21}$ Still clinging tenaciously to the vanishing fiction that a debt is domesticated with the creditor, there appears a new fiction, which places the debt for purposes of garnishment at the debtor's domicile. The result, it is believed, is sound and in accord with the basic note of attachment, that power to control spells out jurisdiction. Since the garnishee is domiciled in New York, and must be personally notified, this physical factor is abundantly satisfied. But the unfortunate emphasis upon the domicile of the debtor and the fictitious assumption that the noted exception is limited to process directed to the garnishee at this location portend difficulties to be presently considered.

\section{WHEN NEITHER THE DEFENDENT NOR THE GARNISHEE IS DOMICILED IN NEW YORK}

Before attempting the analysis of the New York law in the stated circumstances, it is in order to note the rule prevailing in the United States Supreme, ${ }^{22}$ Federal, ${ }^{23}$ and many State ${ }^{24}$ Courts.

${ }^{20}$ Supra note 18.

${ }^{21}$ Douglass v. Phenix Ins. Co. (1893) 138 N. Y. 209, 33 N. E. 938; National Broadway Bante v. Sampson (1904) 179 N. Y. 213, 71 N. E. 766.

22 Harris v. Balk (1905) 198 U. S. 215, 25 Sup. Ct. 625; Louisville \& N. RR. v. Deer (1906) 200 U. S. 176, 26 Sup. Ct. 207; Pennington v. Fourth Nat. Bank (1917) 243 U. S. 269 , 37 Sup. Ct. 282.

${ }^{23}$ Luhrig v. Interstate Coal Co. (1922, S. D. N. Y.) 281 Fed. 265; Atchison T. \& S. Ry. v. Wells (1923) 285 Fed. 369.

24 The prevailing rule, particularly since the decision of Harris v. Balle, in the state courts has been in accord with the principles of jurisdiction 
In the leading case of Hamis $v$. Ballits the question of the power of a state court to garnish a debt arising between non-residents was definitely asked and answered. One Epstein, a resident of Maryland, started an action against his debtor, Balk, and garnished a debt owing from Harris to Balk, both residents of North Carolina. Personal service was made upon Harris, the garnishee, in Maryland; and constructive service alone was made upon Balk, who did not appear to defend. Harris paid to Epstein the money due Balk, and was later sued by Balk upon the same debt in North Carolina. To the argument that the debt was localized at the garnishee-debtor's domicile in North Carolina, and was therefore not attachable by personal service upon the garnishee temporarily present in Maryland, the court, per Peekham, J. answered:

"The obligation of the debtor to pay the debt elings to and accompanies him wherever he goes. He is as much bound to pay his debt in a foreign State when therein sued, as he was in the State where the debt was contracted. Tre speak of ordinary debts such as the one in this case. It would be no defence to such suit for the debtor to plead that he was only in the foreign State casually or temporarily. His obligation to pay would remain the same whether he was there in that way or with an intention to remain. It is nothing but the obligation to pay which is gainished or attached." 20

Thus defined, there is a complete abandonment of the old idea that domicile, either of the creditor or the debtor, harbors and determines the situs of a debt for the purpose of attachment. A debt is migratory, not fixed. It follows the person of the debtor and can be reached by foreign attachment directed to the garnishee, and this too in the absence of any independent jurisdiction over the principal defendant.

Once more fiction breaks down under pressure of fact, and succumbs to the central principle governing the attachment of tangible property with its emphasis upon the power to control as the prime jurisdictional factor. There is much to be said in favor of the rule of Harris $v$. Balk as a solution of the veratious problem of the localization of debts. It is directed to the mobility of debts, a mobility which has increased in these modern times with space-destroying inventions which have reduced distances and

enunciated therein. National Fire Ins. Co. v. Chambcrs (1593) 53 న. J. Eq. 468, 32 Atl. 663; Baltinore \& Ohio $R$. R. 2. Adams (1908) 150 Ind. 6ss, 66 N. E. 43; Stone v. Drake (1906) 79 Ark. 384, 96 S. W. 197; Tiencr a. American Ins. Co. (1909) 224 Pa. 292, 73 Atl. 443; Eristol a. Brent (1910) 38 Utah, 58, 110 Pac. 356; Starliey v. Clcrelaid, ctc. R. R. (1911) 114 IIinn. 27,130 N. W. 540; Leech v. Brown (1915) 172 Iowa, 182, 154 N. W. 440; Bingenheimer Co. v. Weber (1922, N. D.) 191 N. W. 620; see also Ben?e. op. cit. supra note 5 , at 118.

25 Supra note 22.

28 Ibid. at 222-223; italies ours. 
erased boundaries. Business is no longer local, but national and even international, in its scope and ramifications. It seems rather fantastic to hold to a fiction that a debt is lodged at the domicile of the debtor, when the fact is that he does not leave his obligations behind him. Again, commerce and business are conducted upon credit with the resultant substitution of intangible wealth for tangible property. Can the law hide behind a fiction in the face of these palpable and important changes in the world about? Harris v. Balk has answered these questions in the negative.

But New York parts company with the United States Supreme Court when neither the defendant nor the garnishee is domiciled in the state, and refuses the remedy of garnishment to the plaintiff. It rejects the transient qualities of the debt developed in Harris v. Balk and insists that it is restricted to the domicile of the creditor or the debtor. In a leading case, Douglass v. Phenix Insurance Company, ${ }^{2 \pi}$ the Court of Appeals said:

"The general rule is well settled that the situs of debts and obligations is at the domicile of the creditor. But the attachment laws of our own and of other states recognize the right of a creditor of a non-resident to attach a debt or credit owing or due to him by a person within the jurisdiction where the attachment issues, and to this extent the principle has been sanctioned that the laws of a state, for the purposes of attachment proceedings, may fix the situs of a debt at the domicile of the debtor."

With few exceptions ${ }^{28}$ the New York decisions continue to accept the case of Douglass $v$. Phenix Insurance Company as a true expression of the nature and situs of debts for the purpose of garnishment. ${ }^{20}$

25 Supra note 21. In this case the plaintiff, a resident of New York, sued the defendant, a domestic corporation, upon a claim arising out of a policy of insurance. The defendant pleaded in abatement that it was carrying on business and maintaining an agency in Massachusetts under license granted by that state; that, pursuant to the laws therein, it had appointed an attorney in the state for the acceptance of service; that prior to the commencement of the suit in New York, an action was brought against the plaintiff by his creditors in Massachusetts, in which action the defendant insurance company was made a party as trustee, was duly sorved and the debt owing to its New York creditor garnished. It was further alleged that this action in Massachusetts was pending and that Massnchusetts had thereby acquired full jurisdiction over the attached debt. The demurrer to this plea was sustained.

28 See infra notes 67, 68, 69.

${ }^{29}$ Carr v. Corcoran (1899, 1st Dept.) 44 App. Div. 97, 60 N. Y. Supp. 763; Allen v. United Cigar Stores Co. (1902, Sup. Ct. T. T.) 39 Misc. 500, 80 N. Y. Supp. 401; National Broadway Bk. v. Sampson, supra noto 21; Bridges v. Wade, supra note 16; Morris Plan Co. v. Miller (1918, Sup. Ct.,) 102 Misc. 470,169 N. Y. Supp. 37.

The latest case which accepts and applies the doctrine of Douglass $v$. Phenix Ins. Company is Cohn v. Enterprise Dist. Corp. (App. Div., 1st 
The three formulas behind the New York law may be paraphrased in the terms of Douglass v. Pheni: Insurance Company ${ }^{3}$ as follows:

(1) The debt is fixed at the domicile of the creditor or the debtor for purposes of attachment.st

(2) A foreign corporation has "its exclusive residence and domicile in the jurisdiction of origin" and, therefore, it cannot be garnished in another jurisdiction so as to make the attachruent effectual against its creditor in the absence of jurisdiction acquired over the person of such creditor. ${ }^{32}$

(3) If, under the circumstances stated in (2), a sister state issues a judgment against the foreign garnishee-corporation, New York may disregard this judgment as offensive to the course of common-law jurisdictional requirements." :

As to the first and third contentions, the stated restrictions extend to both non-resident individuals ${ }^{34}$ and to foreign corporations, ${ }^{35}$ when served as garnishees outside their respective domiciles. The second limitation obviously is referable only to corporate entities. It is purposed to examine the validity and justice of the procedural fictions which (1) localize the debt at the domicile of the creditor or the debtor, (2) confine a foreign corporation to its domicile of origin, and (3) refuse extra-territorial effect to judgments issued in defiance to these jurisdictional inhibitions.

\section{I}

Keeping in mind that New York has abandoned the rigid rule that a debt is imbedded at the domicile of the creditor-defendant when the defendant is a non-resident and the garnishee is domiciled in New York, ${ }^{36}$ there remains no valid reason for the limitation that the garnishee must be domiciled at the forum if satisfactory and direct service in personam is made upon the latter outside of his domiciliary abode. It is too late for New York to argue that a garnishable debt calls for jurisdiction over the persons of the creditor and the debtor, an argument consistently

Dept., N. Y. L. Jour., Nov. 30, 1925. See Kennedy, Jurisdiction Orer Debts, N. Y. L. JoUR., Dec. 21, 1925.

30 Supra notes $21,27$.

s1 Supra note 21, at 219.

32 Ibid. at 220-224.

33 Ibid. at 221.

34 Ibid.; National Broadway Banl: 2. Sampson, supra note 21; Carr 2. Corcoran, supra note 29.

35 Douglass v. Phenir Iis. Co., supra note 21, at 221; Allen i. Cinitcd Cigar Stores Co., supra note 29; Coln v. Entcrpriso Dist. Corp., supre note 29.

is Supra note 21. 
and ably made by Professor Beale ${ }^{37}$ and persuasively answered by Professor Carpenter. ${ }^{38}$ The injustice, if any, in the operation of Harris $v$. Balk ${ }^{39}$ results. from the seizure and payment of a credit belonging to the non-resident defendant after constructive notice. It is not conceivable that the garnishee has any ground to complain, if he is personally protected and served within the jurisdiction of attachment proceedings, whether he is domiciled there or not. Yet this is the very effect of the New York rule-if the garnishee is domiciled in New York, an incident of no effect in removing the alleged injustice against the non-resident defendant, the credit of the absent defendant is seized and sold; if the garnishee is not domiciled herein, the same credit is immune from attachment. Assuming, as is frequently the case, that the plaintiff in the main action is a resident of New York, the rather startling situation follows: A resident plaintiff's access to a credit owing to a non-resident defendant from a non-resident garnishee (even when the latter is personally served in the state) is dependent, not upon the justice or injustice of the garnishment process as it affects the non-residents, one or both, but solely upon the mythical situs of the debt garnished at the domicile of the debtor. And moreover, the resident plaintiff discovers that this fiction is not only potent enough to defeat ancillary relief, but is likewise destructive of jurisdiction over the defendant in the main action. ${ }^{40}$

As a vehicle of justice, it is submitted that the fiction which solidifies the debt at the garnishee's domicile is unduly, although unintentionally, favorable to non-resident defendants, correspondingly unfair to plaintiffs (particularly resident plaintiffs) privileged to sue in New York, and without merit with reference to the rights of the garnishee, the very person whose status admits or defeats garnishment. Nor can the blame be placed at the doors of the Legislature; the statutes ${ }^{41}$ and the admissions of the

\footnotetext{
${ }^{37}$ Supra note 5.

38 Supra note 5.

${ }^{39}$ Supra note 22 . This possible injustice to the non-resident is mitigated in Harris v. Balk by the provision that the right of the garnishee to avail himself of the prior judgment and payment to the principal plaintiff, when sued by the non-resident defendant, is conditioned upon the garnishee's notification to the non-resident of the pendency of the garnishment proceedings.

The claim of the garnishee that he is discommoded, his property and contract rights invaded, by the garnishment writ is without merit. Endicott Johnson Corp. v. Encyclopedia Press, supra note 11.

${ }^{40}$ Cohn v. Enterprise Dist. Corp., supra note 29.

41 N. Y. C. P. A. 1921 , secs. $684,916,917$. No limitation is imposed by these sections beyond personal notice to the garnishee in New York. The qualification that the garnishee must be domiciled in the state is wholly absent. People v. St. Nicholas Bi. (1899, 1st Dept.) 44 App. Div. 313, 60 N. Y. Supp. 719; Weil v. Gallun (1902, 1st Dept.) 75 App. Div. 439,
} 
judges ${ }^{42}$ lend force to the conclusion that this insistent adherence to domicile as a jurisdictional test of garnishment is purely judicial in origin. Passing the question whether the source from which the fiction came should be privileged to revise it without legislative aid (and the writer believes that there are ample grounds for an affirmative answer) ${ }^{43}$ it is hardly conceivableespecially in a commercial state where credit is interwoven into the ideas of property and wealth, where the bulk of the business of America is localized, where non-residents, individual and corporate, enjoy the commercial advantages on the same plane as residents-that the legal fiction that a debt is only attachable or garnishable at the domicile of the debtor-garnishee can permanently endure.

\section{II}

The fiction that a foreign corporation is a thoroughly domesticated entity and that it has "its exclusive residence and domicile in the jurisdiction of origin" deserves separate consideration, as a restrictive doctrine in the law of attachment of intangible debts. If this fiction is unsound with reference to the residence of corporate garnishees, if the nomadic activities of modern life penetrate the veil of corporate existence and disclose that these corporations are in fact abroad in the land, leading a double or multiple life, another cornerstone of Douglass w. Phenia Iasurance Company is undermined, another fiction fades away under the illuminating facts of modern commercial life. And New York may gracefully apply this altered concept of dual or multiple residence as an adequate basis for reaching foreign-born corporations by way of garnishment, without the necessity of executing a turnabout-face in its prior holding that the debt is located at the residence of the corporation.

The fiction that a corporation leads a cloistered and solitary

78 N. Y. Supp. 300; Starlee v. Beckwith Spccial Agency (1019) 227 N. Y. 42,124 N. E. 96.

${ }_{42}$ Douglass v. Phenix Ins. Co., supra note 21, at 221-222; Plimpton v. Bigelow (1883) 93 N. Y. 592, semble; Carr v. Corcoran, supra note 29, at 764 ; ef. note 2 , supra.

43 The temperate and moderate judicial review of former decisions, when past precedents are clearly inapplicable to modern conditions, and their readjustment to meet the changing social order, may be noted in New York law. People v. Schweinler Press (1915) 214 N. Y. 395, 108 N. E. 639; Klein v. Maravelas (1916) 219 N. Y. 383, 114 N. E. 809; Epstein $v$. Gluckin (1922) 233 N. Y. 490, 135 N. E. 861; Oppcincim v. Kridel (1923) 236 N. Y. 156,140 N. E. 227.

But ef. Sun Print. Co. v. Remington P. \& P. Co. (1923) 235 N. Y. 338, 139 N. E. 470; Imperator Realty Co. v. Tull (1920) 228 N. Y. 447, 127 N. E. 263; Crowley v. Lewis (1925) 239 N. Y. 264, 143 N. E. 374; Cammacl: v. Slattery (1925) 241 N. Y. 39, 148 N. E. 781. 
life in the state that gave it birth and that it cannot be reached by process outside of the state of its incorporation came into New York law by force of a dictum in Matter of McQueen $v$. Middleton Manufacturing Company"s to the effect that "the process against a corporation must be served on its head, or principal officer, within the jurisdiction of the sovereignty where the artificial body exists." This dictum played a prominent part in shaping the early law of other jurisdictions. ${ }^{45}$ But the answer to this narrow doctrine had been made many years before its qualified revival in the Douglass case ${ }^{46}$ and in the meantime, New York found no insuperable difficulty in upholding statutes which nullified the "eternal principle" that a corporation could not be served with process outside of the chartering state.47 Moreover, New York had consistently held since 1873 that foreign insurance companies, which seek and receive permission to do business in the state, "must be regarded as domiciled here" at least "as to business transacted" ${ }^{48}$ in New York. But the principle of the singleness of corporate residence persisted in other phases of corporation law ${ }^{49}$ Thus in the evolution of New York

14 (1819, N. Y. Sup. Ct.) 16 Johns. 5.

¿5 Peckham v. North Parish (1834, Mass.) 16 Pick. 274; Middlebroolis v. Springfield Fire Ins. Co. (1841) 14 Conn. 301; Henderson, The Position of Foreign Corporations in American Constitutional Law (1918) 79.

${ }^{46}$ Moulin v. Trenton Mutual Life Ins. Co. (1855) 25 N. J. L. 57; St. Clair v. Cox (1882) 106 U. S. 350, 1 Sup. Ct. 354.

${ }^{47}$ Hiller v. Boston \& Maine $R$. R. (1877) 70 N. Y. 223; Pope v. Terro Haute Car Co. (1881) 87 N. Y. 137.

${ }_{48}^{4}$ Martine v. International Life Ins. Soc. (1873) 53 N. X. 339; Morgan v. Mutual Life Ins. Co. (1907) 189 N. Y. 447, 82 N. E. 438; Comey v. United Surety Co., supra note 15.

Sed quere, whether the right to sue foreign insurance companies, licensed to do business and actually doing business therein, should be restricted to causes of action arising out of business done in New York. N. Y. Insurance Law, sec. 9, 30; cf. Stock Corp. Law, sec. 110, 111; note 15, supra.

49 The question of the domicile or residence of a foreign corporation arose in connection with the defence of the Statute of Limitations. Could a foreign corporation having property, offices and officials, and doing business in New York without a license invoke the aid of this statute when sued in New York? The law of New York excepted from the time limited for the commencement of an action the period during which the defondant was absent from the state. N. Y. C. P. A. 1921, sec. 19; C. C. P., sec. 401; Code Proc., sec. 100. Construing this section, it was held that a foreign corporation ex necessitate was always absent from the state, since it dwolt only in the state of origin, and therefore, it could never seek refugo in the defence of the Statute of Limitations. Olcott v. Tioga $R$. R. (1859) 20 N. Y. 210; Rathburn v. North Carolina $R$. R. (1872) 50 N. Y. 656; Boardman v. Lake Shore \& Mich. S. Ry. (1881) 84 N. Y. 157. The anomaly of locating a foreign corporation, for procedural purposes, permanently outside of New York in defiance of the patent facts, and then calmly proceeding to try the same cause of action against the foreign corporation in its courts has not escaped criticism. Tioga R. R. v. Blossburg \& Corning $R$. $R$. (1873, U. S.) 20 Wall. 137, 143, 152. In Comey v. United Suraty 
law governing jurisdiction over foreign corporations there are two violently contrasted principles contesting for the mastery. One rule justified service upon a foreign corporation even when it did no business, had no offices or property in New York provided only that the proper official had been served within the state. And the mere fact that the official served was not upon the business of the corporation or was upon a pleasure trip made no difference in drawing the foreign corporation into New York for the purposes of suit. ${ }^{50}$ The other rule denied that a foreign corporation could be present in New York even when it did business, owned property and maintained offices in the jurisdiction.52

Faced by these parallel and inconsistent theories of corporate residence, the problem came forth in another form in Douglass v. Phenia Insurance Company with reference to the situs of corporations for the purpose of attachment.". In view of, the general breakdown of the dictum enunciated in Matter of McQucen v. Middleton Manufacturing Company ${ }^{53}$ nearly three-quarters of a century before the Douglass case, the liberal interpretation of New York statutes regarding service upon foreign corporations, ss especially with reference to foreign insurance corporations, ${ }^{55}$ and particularly because of statutory permission which allowed the courts to reach a foreign corporation by garnishment under the stated conditions, ${ }^{56}$ it would seem that the time had arrived for New York to recognize the jurisdiction of a state over a foreign corporation, doing business under license of the state, to the point of garnishment of intangible debts owing to non-residents of the

Co., supra note 15 , the Court of Appeals refused to extend this untenable doctrine to the case of a foreign insurance corporation licensed to do business in New York. As to this corporation, the Court said, per Cardozo, J.: "We think that a foreign corporation thus licensed under our own laws may not with reason be held to be absent from our state. It owes to the law of its creation its franchise to be a corporation; but it owes to the law of this state the privilege of doing business within our borders. In exercising that privilege it may be dealt with as if it were in truth a domestic corporation. - . . We hold, therefore, that the defendant has the right, like a domestic corporation, to take advantage of the defense that the action was not begun in time." $217 \mathrm{~N}$. Y. at 274, 276, $111 \mathrm{~N}$. E. at 834 .

so Supra note 47. These earlier and untenable views of jurisdiction over foreign corporations not doing business in New York are now discarded. Dollar Co. v. Canadian C. \& F. Co. (1917) 220 N. Y. 270, 115 N. E. 711. But the change was not due to any voluntary action of the New York courts; they yielded to the contrary views of the United States Supreme Court. Dan River Cotion Mills v. Menefee (1915) 237 U. S. 189, 35 Sup. Ct. 579.

51 Supra note 49.

52 Supra note 27.

53 Supra notes $44,46$.

54 Supra note 47.

5s Supra note 48.

${ }^{56}$ Supra note 41. 
forum. Moreover, New York had already accepted by clear dicta the justice of this extension of the garnishment process. ${ }^{57}$ But the shades of Matter of McQueen $v$. Middleton Manufacturing Company still stalked about and the antiquated notion of corporate domicile prevailed.ss There are grounds for the belief that this discredited fiction will be squarely repudiated when it is presented to the Court of Appeals. ${ }^{\text {c9 }}$ Until then, it provides an apt illustration of Pollock's criticism; it is a "stubborm bit of archaic form" which still stands out in New York law.

\section{III}

The positive declaration in the Douglass case ${ }^{30}$ that New York is not bound to recognize.the judgment of a sister state issued against a foreign garnishee in the absence of jurisdiction over the principal defendant, even though personal service is accomplished upon the garnishee in the forum, must now be deemed to be overruled by force of the full faith and credit demanded of this judgment by Harris $v$. Balk. ${ }^{61}$ Concededly New York may still refuse to take jurisdiction over foreign garnishees within the state, despite the constitutional integrity of jurisdiction thus exercised. But it cannot withhold recognition from a foreign judgment of another state similarly obtained. ${ }^{\circ 2}$ Nor is the effect of Harris $v$. Balk limited to its decree of inviolability in the case of extraterritorial judgments against non-resident garnishees. The New York decisions press down upon the "embarrassing conflict of jurisdictions" that would follow the localization of a debt with a foreign corporation doing business in several states. ${ }^{.3}$ This fear is no longer formidable in view of the protection accorded to the foreign corporation after paying its debt according to the terms of Harris v. Balk. Another objection raised in the Douglass decision was the commendable one that the suggested expansion of garnishment would "subject creditors of domestic corporations to great prejudice." 64 This was true in cases where domestic corporations doing business abroad were subjected to the garnishment process, thus depriving local creditors of their credits by actions begun in other states. But New York must now accept

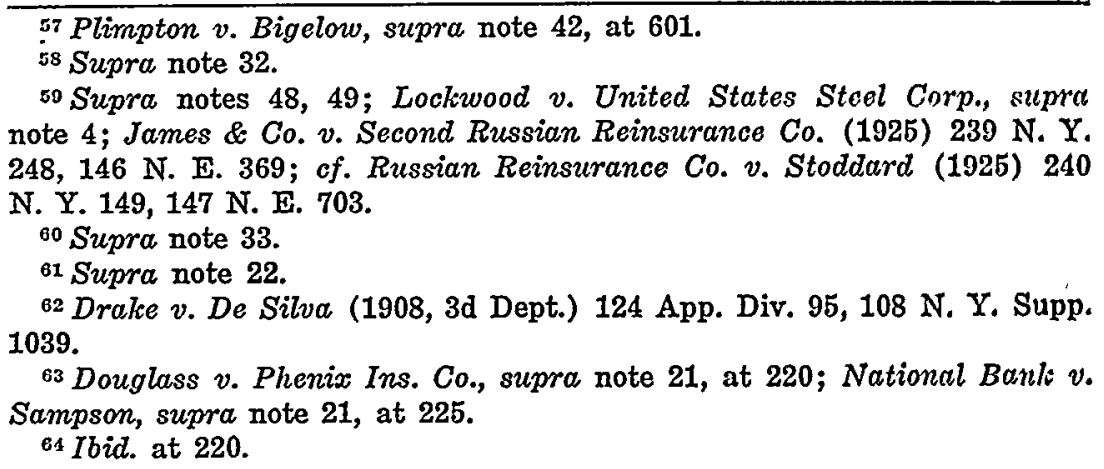


the result of Harris $v$. Balli which permits these credits to be diverted from the creditors of New York corporations. MIoreover, the present New York rule in action has resulted in the penalizing of local creditors in their pursuit of attachable assets of nonresident defendants. ${ }^{\circ 5}$

Concluding the survey of the present validity of the three un-

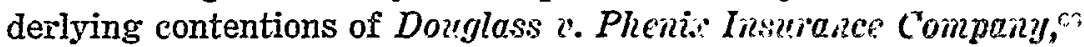
it may be said that one principle alone holds back the entry of Harris $i$. Balk into New York: the fiction that an intangible debt has an irremovable situs at the domicile of the creditor or the debtor when its attachment is sought. And even this persistent doctrine is being weighted with limitations that evince a readiness to abandon it upon rather slender and apparently unsound distinctions. Thus, an attachment of a debt owing from a foreign garnishee to a non-resident has been permitted if the debt arose out of a contract made and payable, ${ }^{n:}$ or performed in New Yorls, ${ }^{63}$ or if the business which gave rise to the debt originated in the state. ${ }^{69}$ While these decisions are pointed in the right direction, in that they invade the heretofore inflexible axiom that the delst is fixed at the domicile of the creditor or the debtor, the inference that the place of contract, payment, or performance in itself spells out a situs of the debt is somewhat debatable. These incidents are essential in determining contractual ioghts, but it is questionable whether they can justify the exercise of remcdios generally denied. If New York still insists, as it does, that the situs of the debt is determined by domicile, and therefore not attachable when the defendant and the garnishee are non-residents, the mere maling of the contract, or its performance, in New Fork should not shift its situs to this state. ${ }^{\circ}$ The truth is that personal and direct control over the garnishee within the state was the prime jurisdictional factor in these cases; and the emphasis upon collateral elements served to postpone the full force of this ultimate adjudication.

In conelusion, it is submitted that New York should remove this remaining "bit of archaic form" which links and restricts the gar-

65 "The courts of this state were primarily for the residents of this state. There must be some forceful and controlling reason entering into the very nature and essence of the action which would close their doors to its own citizens." Gregonis v. Philadclphia of Rcading Codl Co. (1939) 235 N. Y. $152,159,139$ N. E. $223,225$.

Supre nctes $31,32,33$.

- Lancaser i. Sprtavood (1903, Sup. Ct. Spee. T.) 11 Mise. 19, 83 :. X. Sipy. 572 .

Flinn \%. Write (1907, 1st Dept.) 122 App. Div. 780, 107 N. Y. Supp. 869.

India Ribber Co. v. Fatz (1901, 1st Dept.) 65 App. Div. 340,72 ห. T.

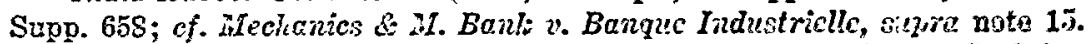

ro Harriz v. Ball, supra note 37, at 222; Tauza z. Susquchanza Coal Co., sing note 16, semble. 
nishment of intangible debts to the domicile of creditor or debtor. This fiction is not demanded by the constitutional provisions of due process, nor is it imposed upon the courts by legislative mandate. Tested in the scales of justice-which is the sole warrant for the continuance of its fictitious existence-it is arbitrary and unfair to plaintiffs, generally New York citizens or domestic corporations, and unduly mindful of the interests of non-resident defendants and garnishees. Tested in terms of the emergencies and tendencies of the time, this static idea of domicile as a sort of safe-deposit vault for intangible debts is a curious relic in the midst of the fluidity of modern business with its interstate transactions, extension of credit and transient agencies. Assuming direct notice to the non-resident garnishee in the forum and ample opportunity to the non-resident defendant to protect his rights when served by publication-and these essentials are already insured by the existing statutes of New York ${ }^{71}$ and the restrictive provisions of Harris $v$. Balk ${ }^{72}$-a plaintiff should be given free access to this intangible asset by way of garnishment without reference to the fading fiction of domicile.

${ }^{72}$ N. Y. C. P. A. 1921, secs. $217,493,819$.

¿2 Supra note 39. 